\section{In Paraguay, both IUDs and contraceptive pills come with "strings attached"}

\author{
Dawn S. Chin-Quee ${ }^{1}$
}

Key words: intrauterine devices; contraceptives, oral; family planning services; quality of health care; Paraguay.

\footnotetext{
Family Health International, Durham, North Carolina, United States of America. Send correspondence to: Dawn S. Chin-Quee, Family Health International, 2224 E NC 54, Durham, NC 27713, United States of America; telephone: (919) 544-7040, ext. 473; fax: (919) 5447261; e-mail: dchin-quee@fhi.org
}

Despite government-sponsored efforts to develop, disseminate, and institutionalize national family planning guidelines, many providers in Latin America do not always comply with guideline recommendations, which are generally intended for public sector providers. The reasons for this noncompliance range from lack of knowledge of the guidelines to providers' deeply held personal or cultural beliefs that run counter to the guideline recommendations. ${ }^{2}$ Providers have also been known to exhibit deliberate resistance to training. For example, one provider who attended a family planning training session in El Salvador reported that, even after four days of training, other providers in the session still believed the myth that the intrauterine device (IUD) is an abortifacient (1). Responding to community expectations on gender roles in order to avoid later problems with the husband of a female client has also been documented (2). Providers sometimes pick and choose which recommendations to follow. In Peru, for instance, there has been selective noncompliance with standards on voluntary surgical contraception $(3,4)$.

Very few studies in Latin America have explicitly assessed provider adherence to national family planning guidelines. Many more instances of provider noncompliance with guidelines have been anecdotal, or they have been noted in the course of studies that examined related issues of family planning service delivery. Cumulatively, these accounts suggest that provider noncompliance constitutes a significant barrier to the provision of reproductive health and family planning services in Latin America.

\section{ADHERENCE TO FAMILY PLANNING GUIDELINES IN PARAGUAY}

In 1996, Family Health International (FHI) and the Paraguayan Ministry of Public Health and Social Welfare conducted a series of regional contraceptive technology update workshops. FHI is a nonprofit international public health organization that manages research and field activities worldwide. As part of its mission to improve lives through research, education, and services in family health, FHI periodi-

\footnotetext{
2 Expanding options in reproductive health: assessment to identify priority interventions for improving access to and quality of essential maternal health services in Guatemala. Restricted draft. Geneva: World Health Organization; 2002.
} 
cally provides updates on the latest information on contraceptive methods and services to public sector and private sector family planning providers in Latin America. The participants in the workshops in Paraguay, who were primarily public sector providers, identified the lack of up-to-date guidelines for family planning service delivery as a significant barrier to the provision of high-quality care. The participants strongly recommended that, as a strategy to overcome this barrier (5), the Ministry of Health and Social Welfare revise and update the existing national family planning guidelines and then disseminate the amended version. During the process of updating the guidelines, the Ministry of Public Health and Social Welfare decided to evaluate the impact of dissemination of the revised recommendations. The goal was to allow the Ministry to determine the most effective means of producing provider compliance with the guidelines. Using the Ministry's plan for disseminating the guidelines, FHI conducted an evaluation study to determine the most effective means of achieving provider compliance with the newly revised recommendations.

For the evaluation study, provider knowledge, attitudes, and practice (KAP) before the providers were exposed to the new guidelines document in April 1998 was compared with provider KAP 12 to 22 months later (April 1999 to February 2000). (A change in government personnel and several strikes delayed data collection efforts throughout the study.) A quasi-experimental design was developed, in which three different levels of guideline exposure or dissemination strategies were assigned to 40 health facilities from four health districts in Paraguay. Providers in the control group were not exposed to the guidelines document. Their counterparts at the second and third levels of exposure attended a training workshop on the content and use of the guidelines. Providers at the third level of exposure also received, for six months, supplementary reinforcing visits from their district supervisors and/or printed job aids or "fact sheets" that summarized the contents of the guidelines. During the supervisory visits, the providers and the supervisors had face-to-face meetings to review the guideline recommendations. The fact sheets were distributed on a monthly basis, coinciding with the time of the supervisory visits and dealing with the same topic as those visits.

Provider KAP was assessed via in-depth interviews at baseline and at follow-up with the same 68 providers. These 68 providers came from 34 of the 40 health facilities in the study. Information on actual provider practices came from two sources: (1) exit interviews with 345 clients at baseline and 354 clients at follow-up and (2) observations made by 105 simulated clients at baseline and 108 simulated clients at follow-up. Provider KAP related to guideline recommendations was examined in several areas, including restrictions based on age, parity, breast-feeding, and menstrual status; spousal consent and marriage requirements; frequency and rationale for lab tests and examinations; and content and nature of contraceptive method counseling.

The revised Ministry of Public Health and Social Welfare guidelines drew on documents from the World Health Organization (WHO) (6) and the United States Agency for International Development $(7,8)$, and they also used the Colombian and Mexican national family planning guidelines as references. The revised guidelines in Paraguay outline recommendations for the initiation, provision, and continuation of a wide variety of contraceptive methods available in public sector and private sector health facilities, including hormonal, barrier, nonreversible, long-term, and natural family planning methods. This paper focuses on two of these methods: oral contraceptives and the IUD.

The revised Paraguayan guidelines recommend providing up to a 3-month supply of oral contraceptives to new clients during their initial visit. At subsequent visits, clients can receive up to a 12month supply of pills. However, the Paraguayan guidelines leave the decision on the number of cycles to dispense up to "programmatic, logistical, and access-related issues" (9), thus conferring considerable autonomy on providers. With regard to IUD revisits, the Paraguayan guidelines recommend three visits after insertion of the IUD: at four to six weeks, at six months, and at one year. Even with those recommended three visits, Paraguayan guidelines are at odds with international guidance on IUD followup procedures from $\mathrm{WHO}$ and others $(7,10)$, which call for one visit at three to six weeks after insertion, with no required revisits thereafter.

The most clear-cut and noteworthy finding from our evaluation was providers' reported practicescorroborated by reports from actual and simulated clients - in the area of contraceptive provision and follow-up procedures. Regardless of their level of exposure to the guidelines, more than half of the 68 providers at baseline and at follow-up indicated that they would give only one cycle of pills to new users and no more than two cycles to continuing users. Further, more than half of the 68 providers at baseline and at follow-up, irrespective of guidelines exposure, recommended more than three checkup visits during the first year of IUD use, with five visits being routine.

Strictly speaking, the practice of dispensing no more than two cycles of pills at a time to any user does not conflict with the wording of the revised Paraguayan guidelines. However, these practices can be seen as going against the spirit of the guidelines, especially in light of providers' reasons for limiting 
the number of cycles per visit. At the time of the study, oral contraceptives were not in short supply, and two reasons were given for the provision of so few cycles per clinic visit. One reason was that providers wanted to make sure that clients understood that they should take one pill per day. As such, the clients were required to return to the clinic for resupply and reeducation every one to two months. A second reason was that providers believed that if they dispensed more than a few cycles of pills to clients, the women would give their packets to friends and neighbors rather than take the pills themselves.

With regard to the IUD, the Paraguayan providers tended to follow a schedule that included as many as five revisits within the first year. With some variation, they reported adhering to a timetable as follows: Visit 1: eight days after insertion; Visit 2: one month after insertion; Visit 3: between two to three months after insertion; Visit 4: six months after insertion; and Visit 5+: every six months thereafter.

Conversations with Ministry of Health staff revealed that this strict schedule of revisits was intended to give doctors the opportunity to conduct Pap smears with otherwise reluctant clients and to check IUD strings regularly. Fearing that women might become infected if they were encouraged to check the strings themselves, the providers require clients to return often in order to have the strings checked. It is out of this same concern for infection prevention that doctors reportedly discouraged the use of diaphragms in Paraguay (personal communication, Ministry of Public Health and Social Welfare, April, 2000).

\section{DISCUSSION}

While initial access to family planning methods and services does not appear to be a problem in Paraguay, continuity of care-especially for pill and IUD users-may be jeopardized by well-meaning family planning providers. Follow-up and continuity mechanisms are regarded as a component of quality of care (11). However, follow-up and continuity mechanisms that create obstacles or hardships for clients reduce quality of care and hinder family planning continuation. This is particularly true for those pill users for whom resupply involves considerable time and effort to return to the clinic every time they require more pills. It is inappropriate to deny such clients sufficient supplies with the supposed aim of making certain the women understand how to take oral contraceptives. After the first revisit, both the provider and the client should be confident of the woman's ability to use the pill properly. To deny clients sufficient supplies because they may give extra cycles to friends and neighbors is punitive and challenges the notion of providing quality services. As evidenced by our study findings, providers restricted access to oral contraceptives, and the restrictions continued even after clients had undergone counseling, method selection, and initiation. Continuity of care-especially since it involves checkups and resupply-should take into consideration the welfare, needs, and convenience of the clients.

Although continuity of care is clearly indicated by the high number of return visits that IUD users must make, this requirement may not develop into an issue of continuing inconvenience as it would for pill users. Instead, it may become an issue of lost opportunity for the provision of an appropriate method when, after being apprised of the number of recommended return visits, the client decides to reject the IUD. Furthermore, the client may come away with the impression that the IUD is not a safe or stable method, as evidenced by the number of times she is advised to return to make sure the device is in place and that she has not developed an infection. As such, it adds to the poor reputation from which the IUD has suffered for years.

Providers should not recommend an excessive number of revisits for clients. Research in Mexico comparing two versus four IUD revisits showed that the lower number of return visits did not place the IUD user at any greater risk for lower genital tract infection or pelvic inflammatory disease (12). Moreover, other research (13) indicates that when more frequent revisits are required, the IUD clients who are returning for revisits quickly outnumber first-time IUD users. This results in a poor use of resources, particularly when women are not experiencing problems with the IUD. Indeed, only when IUD clients experience symptoms are revisits effective (14) and likely to result in significant cost savings (15).

\section{CONCLUSIONS}

In Paraguay, providers of oral contraceptives and IUDs clearly impose unnecessary barriers to method use and continuation. Compared to international and regional Latin American guidelines, unjustifiable reasons are used to compel pill users to return for resupply and checkups. Similarly, IUD clients in Paraguay are asked to make unnecessary revisits out of exaggerated concerns for infection prevention. The attitudes and beliefs that give rise to these behaviors appear to be cultural and reflect provider expectations of clients' inability to understand and follow instructions on the proper use and maintenance of their contraceptive method. Given the burden that these practices place on clients, the Ministry of Public Health and Social Welfare 
should make a concerted effort to educate the providers in Paraguay not only on the content and the rationale for recommendations contained in the guidelines but also on the importance of respecting and serving clients well. Since the dissemination strategies endorsed by the Ministry were not implemented as planned during the data collection phase of the study, these strategies could be instituted now in order to ensure that all providers are exposed to the document and are given guidance on how to improve family planning services through its use. When available, evidence-based research should also be imparted to providers in order to confer credibility to the recommendations and to assure providers that recommended practices have been tested and proven safe.

Acknowledgements. The work on which this article is based was funded by the United States Agency for International Development. The author would like to express appreciation to Barbara Janowitz and John Stanback for their helpful comments on this and earlier drafts.

\section{SINOPSIS}

\section{En Paraguay, la provisión de dispositivos intrauterinos y de píldoras anticonceptivas está sujeta a demasiadas condiciones}

Según informes anecdóticos, la provisión de servicios de planificación familiar y salud reproductiva en América Latina se ve gravemente obstaculizada por el hecho de que los proveedores de dichos servicios hacen caso omiso de las pautas establecidas para los servicios de planificación familiar. En este estudio, que se llevó a cabo en Paraguay entre 1998 y 2000, se evaluó en qué medida los proveedores de servicios observaban las pautas revisadas y posteriormente publicadas y diseminadas. Los investigadores encontraron indicios de que las nuevas pautas no se observaban en el contexto de la atención continuada de mujeres que usaban dispositivos intrauterinos (DIU) o anticonceptivos orales. Contrario a lo que dichas pautas recomiendan, los proveedores de servicios imponian condiciones, haciendo, por ejemplo, que las usuarias de DIU regresaran a la clínica hasta cinco veces durante el primer año después de la colocación del dispositivo. Las usuarias de anticonceptivos orales también enfrentaron obstáculos, entre ellos el de verse limitadas a no más de dos ciclos de pastillas cada vez, aunque las usaran con regularidad. Según estos resultados, las exigencias que rodean a la provisión y al seguimiento no fomentan, sino que desalientan el uso continuado de DIU y de anticonceptivos orales y podrían llevar a la suspensión de estos métodos por temor a que el DIU no sea seguro y estable o por la incomodidad de tener que volver a la clinica varias veces a recoger las pastillas. Los ministerios de salud en América Latina deben redoblar sus esfuerzos por educar a los proveedores de servicios de planificación familiar en cuanto al contenido y la razón fundamental de las recomendaciones vinculadas con las pautas nacionales. Asimismo, siempre que se disponga de los resultados de investigaciones, estos se deben presentar a los proveedores de servicios para reforzar ante ellos la credibilidad de las recomendaciones y demostrarles que las prácticas recomendadas han sido puestas a prueba y que su inocuidad está demostrada.

\section{REFERENCES}

1. Carranza J, Johnson L, Katz K, Janowitz B. Determining reasons for low IUD use in EI Salvador: final report. Research Triangle Park: Family Health International; 2000

2. Hernandez J, Maldonado M, Tumax J. Evaluación de las barreras médicas a los programas de planificación familiar. Washington, D.C.: Options for Populations Policy II; 1993.

3. León F. Peru: providers' compliance with quality of care norms: final report. Washington, D.C.: Frontiers in Reproductive Health, Population Council; 1999.

4. León F, García I. Peru 2000: compliance with Ministry of Health norms: final report. Washington, D.C.: Frontiers in Reproductive Health, Population Council; 2001.

5. Conn W. Development of national family planning guidelines project. Research Triangle Park: Family Health International; 1997.
6. World Health Organization. Improving access to quality care in family planning: medical eligibility criteria for contraceptive use. Geneva: WHO; 1996.

7. United States Agency for International Development. Recommendations for updating selected practices in contraceptive use: results of a technical meeting. Washington, D.C.: USAID; 1994.

8. United States Agency for International Development. Recommendations for updating selected practices in contraceptive use: volume II. Washington, D.C.: USAID; 1997.

9. Paraguay, Ministerio de Salud Pública y Bienestar Social. Manual nacional de planificación familiar. Asunción: MSPBS; 1998.

10. Stewart G. Intrauterine devices (IUDs). In: Hatcher $\mathrm{R}$, Trussell J, Stewart $\mathrm{F}$, Cates W Jr, Stewart GK, Guest F, et al., eds. Contraceptive technology. New
York: Ardent Media, Inc.; 1998. Pp. 511-43.

11. Bruce J. Fundamental elements of the quality of care: a simple framework. Stud Fam Plann. 1990;21(2):61-91.

12. Hubacher D, Fortney J. Follow-up visits after IUD insertion. Are more better? J Reprod Med. 1999;44(9):801-6.

13. Janowitz B, Hubacher D, Petrick T, Dighe N. Should the recommended number of IUD revisits be reduced? Stud Fam Plann. 1994;25(6 Pt 1):362-7.

14. Neuteboom K, de Kroon CD, DersjantRoorda M, Jansen FW. Follow-up visits after IUD-insertion: sense or nonsense? A technology assessment study to analyze the effectiveness of follow-up visits after IUD insertion. Contraception. 2003; 68(2):101-4.

15. Rivera R, Chi IC, Farr G. The intrauterine device in the present and future. Curr Opin Obstet Gynecol. 1993;5(6): 829-32. 